\title{
AKTIVITAS SITOTOKSIK DAN ANALISIS FITOKIMIA Myrmecodia beccarii Hook.f. ASAL PAPUA
}

\author{
Yuli Astuti ${ }^{1, *}$, Septriyanto Dirgantara ${ }^{1}$, Elsye Gunawan ${ }^{1}$, Komar Ruslan \\ Wirasutisna $^{2}$ \\ ${ }^{1}$ Jurusan Farmasi, Fakultas Matematika dan Ilmu Pengetahuan Alam, \\ Universitas Cenderawasih, Jayapura, Papua \\ ${ }^{2}$ Kelompok Keilmuan Biologi Farmasi, Sekolah Farmasi, \\ Institut Teknologi Bandung, Bandung, Jawa Barat \\ *Email :yuliastuti2758@gmail.com
}

\begin{abstract}
ABSTRAK
Latar belakang dan tujuan : Tumbuhan sarang semut Myrmecodia beccari Hook.f., (family Rubiaceae) adalah tumbuhan obat asli dari Papua yang memiliki potensi secara tradisional sebagai penguat kekebalan tubuh, mengatasi nyeri otot dan mengobati peradangan. Namun, bukti penelitian ilmiah mengenai tumbuhan ini masih sangat terbatas. Tujuan penelitian ini adalah menguji aktivitas sitotoksik dan analisis fitokimia tumbuhan sarang semut. Metode: Ekstraksi dilakukan secara maserasi dengan metanol. Fraksinasi dengan ekstraksi cair-cair menghasilkan fraksi n-heksana,fraksi etil asetat dan fraksi metanol. Penapisan fitokimia dan pengujian aktivitas sitotoksik dilakukan terhadap ekstrak dan fraksi aktif dengan metode Brine Shrimp Lethality Test (BSLT). Fraksi aktif sitotoksik selanjutnya dilakukan analisis dengan Kromatografi Cair- Spektrometer Massa (LC-MS) untuk mengetahui kandungan senyawa kimia yang memiliki potensi aktivitas sitotoksik tertinggi. Hasil dan Pembahasan: Fraksi etil asetat memberikan potensi aktivitas sitotoksik tertinggi dibandingkan dua fraksi lainnya. Fraksi aktif etil asetat mengandung senyawa golongan flavonoid, fenolik dan tanin. Tiga senyawa berhasil diidentifikasi dari fraksi etil asetat yang dianalisa dengan LC-MS. Kesimpulan : Penelitian tentang aktivitas sitotoksik dan analisis senyawa aktif untuk tumbuhan Myrmecodia beccarii Hook.f. ini adalah yang pertama kali untuk spesies tanaman ini dan berhasil diidentifikasi tiga senyawa dari fraksi etil asetat dengan berat molekul senyawa berurutan 291; 563 dan 385 .
\end{abstract}

Kata Kunci : Sitotoksik, fitokimia, Myrmecodia beccarii, LC-MS

\section{PENDAHULUAN}

Tanaman sarang semut (Myrmecodia beccarii) sudah dipercaya dan telah digunakan oleh Masyarakat Papua sebagai berbagai macam pengobatan. Tanaman sarang semut (family Rubiaceae) merupakan tumbuhan obat potensial asli asal Papua yang terbukti secara empiris digunakan masyarakat Papua untuk menyembuhkan berbagai macam penyakit. Secara tradisional tanaman sarang semut telah digunakan sebagai obat oleh masyarakat pedalaman Papua sebagai obat penyembuh radang, menguatkan imunitas tubuh dan mengatasi nyeri otot. Masyarakat setempat memanfaatkan serbuk umbi (hipokotil) tanaman sarang semut sebagai minuman seduhan seperti teh. Salah satu khasiat utamanya adalah membantu pengobatan berbagai jenis tumor dan kanker seperti: kanker otak, kanker payudara, kanker hidung, kanker lever, kanker paru-paru, kanker usus, kanker rahim, kanker kulit, kanker prostat dan leukemia. Tumbuhan sarang semut juga efektif dalam membantu penyembuhan berbagai macam penyakit lainnya, diantaranya gangguan jantung, ambien (wasir), reumatik, stroke ringan mapun berat, maag, gangguan fungsi ginjal dan 
prostat, pegal linu, melancarkan dan meningkatkan jumlah air susu ibu (ASI), melancarkan peredaran darah, dan memulihkan gairah seksual (Natural 2006).

Penelitian yang telah dilakukan hingga saat ini hanya berkaitan dengan kajian ekologi, taksonomi, dan etnobotani, sedangkan penelitian tentang studi fitokimia dan bioaktivitas yaitu isolasi senyawa aktif dari tanaman sarang semut masih sangat terbatas. Dengan demikian penelitian ini memiliki tujuan untuk mengisolasi senyawa aktif sitotoksik tanaman sarang semut Myrmecodia beccarii Hook.f. Tumbuhan sarang semut merupakan tumbuhan epifit yang hidupnya menempel pada tumbuhan lain, seperti pada pohon kayu putih (Melaleuca), cemara gunung (Casuarina), kaha (Castanopsis), dan beech (Nothofagus). Bagian tumbuhan tanaman sarang semut yang digunakan sebagai obat adalah daging hipokotil (caudex). Secara umum ditemukan tiga jenis semut dari genus Iridomyrmex (Huxley, 1993). Tanaman sarang semut terbagi kedalam lima genus yaitu Myrmecodia,Hydnophytum, Myrmephytum, Squamellaria dan Anthorrhiza, namun hanya dua genus yang berasosiasi dengan semut yaitu genus Myrmecodia dan Hydnophytum. Myrmecodia terdiri atas 45 spesies dan Hydnophytum terdiri 26 spesies (Huxley, 1993). Di Thailand, serbuk batangnya digunakan sebagai anticacing, penyakit tulang, nyeri di pergelangan kaki dan bahan untuk pengobatan antidiabetes (De Padua, 1999).

Hasil skrining fitokimia spesies tanaman sarang semut Myrmecodia beccarii terdapat golongan senyawa flavonoid, triterpenoid/steroid, saponin dan tanin (Dirgantara, 2013). Tanaman Sarang semut yang lain (Myrmecodia pendens) dan (Myrmecodia tuberosa) memiliki kandungan senyawa golongan flavonoid,tanin dan polifenol serta alkaloid yang dapat meningkatkan efek proliferasi sel fagositosis (Hertiani, 2010). Tanaman Sarang semut (Myrmecodia pendens) secara moderat dapat meningkatkan aktivitas sel dalam pengobatan kanker payudara dan dan uterus terhadap sel Hela dan sel MCM-B2 (Soeksmanto,2010). Sedangkan dari genus lain yakni Hydnophytum formicarum telah diteliti memiliki aktivitas antimikroba dan antioksidan (Prachayasittikul, 2008). Hasil penelitian Prachayasittikul (2008) ekstrak etil asetat Hydnophytum formicarum Jack. mengandung senyawa stigmasterol, isoliquiritigenin, $\left(2^{\prime}, 4,4^{\prime}\right.$-trihidroksikalkon), protocatechualdehyde (3,4-dihidroksi-benzaldehyde), butin (3,4',7-trihidroksiflavanon) dan butein (2',3,4,4'-tetrahidroksikalkon). Kemampuan bahan aktif untuk membunuh larva udang (brine shrimp) Artemia salina L., merupakan salah satu metode yang disarankan oleh Mc Laughin \& Ferrigni 1983, dalam studi senyawa antitumor dari jaringan tumbuhan, selain pengamatan kemampuan daya inhibisi bahan aktif terhadap pertumbuhan sel tumor pada kentang. Prinsip uji ini adalah komponen bioaktif selalu bersifat toksik jika diberikan pada dosis yang tinggi dan obat adalah racun dari suatu bahan bioaktif dosis rendah (Meyer, et al 1982). Toksisitas senyawa aktif dalam ekstrak tumbuhan ditentukan berdasarkan nilai konsentrasi letal $\left(\mathrm{LC}_{50}\right)$ pada hewan uji Artemia salina Leach Lethal Concentration atau $\mathrm{LC}_{50}$ merupakan konsentrasi senyawa yang mematikan $50 \%$ dari populasi hewan uji. Data mortalitas larva $A$. salina terhadap ekstrak selanjutnya diproses melalui program komputer Probit Analysis Method untuk memperoleh nilai LC $\mathrm{L}_{50}$ dengan selang kepercayaan 95\%. Senyawa dengan nilai $\mathrm{LC}_{50}<1000 \mathrm{ppm}$ dikatakan memiliki potensi bioaktivitas (Meyer et al 1982).

\section{METODE PENELITIAN}

Penelitian ini meliputi beberapa tahapan kerja, yaitu penyiapan bahan, penapisan fitokimia, ekstraksi, fraksinasi, penetapan berat molekul senyawa dari fraksi menggunakan LC-MS yang dipantau dengan pengujian aktivitas sitotoksik dengan metode Brine Shrimp Lethality Test (BSLT). 


\section{Bahan}

Tanaman sarang semut (Myrmecodia beccarii) asal Kabupaten Merake, metanol, nheksana, etil asetat, air laut, amil alkohol, besi (III) klorida, DMSO 1\%, etanol 96\%, $\mathrm{HCl}$, $\mathrm{H}_{2} \mathrm{SO}_{4}$, pereaksi Dragendorff, pereaksi Mayer, pereaksi Liebermann-Burchard, serbuk Magnesium, telur Artemia salina Leach, plat KLT F254, kertas saring, kain hitam dan ragi.

\section{Peralatan}

Alat gelas maserasi, tabung reaksi, aerator, timbangan analitik, corong pisah, gelas beker, lampu, mikro pipet, mortir dan stamper, pengaduk kaca, rotary evaporator, vial-vial, vortex, wadah untuk penetasan telur dan LC-MS.

\section{Prosedur}

\section{Penyiapan Bahan}

Sampel uji tanaman sarang semut dibersihkan dari kotoran yang menempel dengan air yang mengalir hingga bersih kemudian kulit bagian luar yang mengandung duri dibersihkan. Selanjutnya dirajang dengan ketebalan $\pm 1 \mathrm{~cm}$ lalu dikeringkan menggunakan oven pada suhu $\pm 40^{\circ} \mathrm{C}$. Setelah kering simplisia tersebut diserbuk kemudian disimpan dalam wadah bersih dan bertutup rapat.

\section{Ekstraksi}

Metode ekstraksi menggunakan cara maserasi dengan metanol kemudian dilakukan fraksinasi secara ekstraksi cair-cair dengan corong pisah menggunakan pelarut yang berbeda kepolaran yaitu n-heksana dan etil asetat.

\section{Skrining Fitokimia}

Penapisan fitokimia dilakukan terhadap ekstrak dan fraksi aktif meliputi pemeriksaan terhadap golongan alkaloid, flavonoid, saponin, kuinon, tanin dan triterpenoid/steroid (Farnsworth, 1966).

\section{Uji Bioaktivitas Sitotoksik Brine Shrimp Lethality Test (BSLT)}

\section{Penetasan Kista Artemia salina Leach.}

Telur A. Salina Leach ditimbang $\pm 50 \mathrm{mg}$ kemudian dimasukkan ke dalam wadah penetasan telur berisi $500 \mathrm{~mL}$ air laut yang telah disaring dan dipasang aerator, lalu dibiarkan selama 48 jam dengan pencahayaan lampu TL agar telur menetas sempurna. Larva yang sudah menetas dipipet ke dalam botol vial percobaan dan diberi ekstrak sesuai perlakuan.

\section{Persiapan Sampel.}

Larutan seri pengenceran ekstrak dibuat konsentrasi 1000 ppm sebagai larutan induk kemudian dilakukan pengenceran dengan seri 0, 25, 50, 75 dan $100 \mathrm{ppm}$. Larutan fraksi hasil pemisahan dengan corong pisah masing-masing dengan konsentrasi 2000 ppm dibuat dengan cara menimbang $40 \mathrm{mg}$ fraksi dengan teliti kemudian dilarutkan dengan air laut menjadi $20 \mathrm{~mL}$. Ekstrak yang sukar larut, dapat ditambah DMSO 1\% (5 tetes) untuk meningkatkan kelarutan. Konsentrasi $200 \mathrm{ppm}$ dibuat dengan memipet $2 \mathrm{~mL}$ larutan ekstrak 2000 ppm dan ditambah air laut sampai $20 \mathrm{~mL}$. Konsentrasi 20 ppm dibuat dengan memipet $2 \mathrm{~mL}$ larutan konsentrasi 200 ppm dan ditambah air laut sampai $20 \mathrm{~mL}$. Larutan ekstrak 1000 ppm dibuat dengan cara memipet $5 \mathrm{~mL}$ larutan ekstrak 2000 ppm dan ditambah air laut $5 \mathrm{~mL}$. Konsentrasi $100 \mathrm{ppm}$ dibuat dengan cara memipet larutan ekstrak 
$200 \mathrm{ppm}$ sebanyak $5 \mathrm{~mL}$ dan ditambah air laut $5 \mathrm{~mL}$. Larutan ekstrak $10 \mathrm{ppm}$ dibuat dengan cara memasukkan larutan ekstrak 20 ppm dan ditambah $5 \mathrm{~mL}$ air laut.

\section{Uji Bioaktivitas.}

Uji bioaktivitas dilakukan dengan memasukkan 15 ekor larva udang A. salina Leach yang berumur 48 jam ke dalam botol vial yang telah berisi larutan ekstrak dan air laut. Untuk setiap konsentrasi dilakukan 3 kali ulangan (triplo). Sebagai kontrol adalah air laut yang tidak diberi ekstrak sampel. Botol vial percobaan disimpan dibawah pencahayaan lampu TL. Pengamatan dilakukan setelah 24 jam. Jumlah larva udang yang mati dicatat kemudian dihitung persentase kematiannya. Data yang diperoleh dianalisis menggunakan Probit Analysis Method untuk menentukan $\mathrm{LC}_{50}$ dengan selang kepercayaan $95 \%$.

\section{Analisis Kandungan Senyawa Pada Fraksi.}

Untuk mengetahui kandungan senyawa murni yang terkandung dalam fraksi dengan hasil uji bioaktivitas sitotoksik tertinggi maka fraksi dianalisis menggunakan Spektrofotometer LC-MS.

\section{HASIL DAN PEMBAHASAN}

\section{Penapisan Fitokimia Ekstrak}

Hasil penapisan fitokimia ekstrak metanol tanaman sarang semut Myrmecodia beccarii Hook. f. tertera pada tabel berikut:

Tabel 1. Hasil Penapisan Fitokimia Ekstrak (Farnsworth,1966)

\begin{tabular}{|c|c|}
\hline Golongan & Hasil \\
\hline Alkaloid & - \\
Flavonoid & + \\
Triterpenoid/ Steroid & + \\
Kuinon & - \\
Saponin & - \\
Tanin & + \\
\hline
\end{tabular}

Keterangan : + terdeteksi

- tidak terdeteksi

Dari hasil penapisan fitokimia diketahui bahwa ekstrak metanol tanaman sarang semut Myrmecodia beccarii Hook.f. mengandung senyawa golongan flavonoid, triterpenoid/steroid dan tanin. Ekstrak metanol tanaman sarang semut Myrmecodia beccarii Hook.f. tidak mengandung senyawa alkaloid dan kuinon. Pada penelitian penapisan fitokimia spesies tanaman sarang semut lainnya yaitu ekstrak air spesies Myrmecodia pendens Merr.\&Perry diketahui mengandung senyawa golongan tanin dan flavonoid (Soeksmanto,2010) sedangkan ekstrak air spesies Myrmecodia tuberosa Jack. mengandung senyawa golongan flavonoid dan antosianidin (Hertiani,2010).

\section{Penapisan Fitokimia Fraksi Hasil Ekstraksi Cair-cair (ECC)}

Terhadap fraksi yang diperoleh, kemudian dilakukan penapisan fitokimia untuk mengetahui kandungan senyawa secara umum dalam ketiga fraksi. 
Tabel 2. Hasil Penapisan Fitokimia Ketiga Fraksi Myrmecodia beccarii Hook.f.

\begin{tabular}{|c|c|c|c|}
\hline Golongan & n-heksan & Etil asetat & Metanol \\
\hline Alkaloid & - & - & - \\
Flavonoid & - & + & + \\
Triterpenoid/ & + & + & - \\
Steroid & & - & - \\
Kuinon & - & - & - \\
Saponin & - & + & + \\
Tanin Galat & - & & \\
\hline
\end{tabular}

Keterangan : + terdeteksi

- tidak terdeteksi

Berdasarkan hasil penapisan fitokimia ketiga fraksi tanaman sarang semut Myrmecodia beccarii diketahui bahwa fraksi etil asetat dan fraksi metanol mengandung senyawa flavonoid dan tanin. Senyawa triterpenoid/steroid terdapat di fraksi n-heksana dan fraksi etil asetat. Dari hasil penelitian penapisan fitokimia terhadap spesies tanaman sarang semut lainnya yang dilaporkan oleh Soeksmanto (2010) bahwa fraksi etil asetat Myrmecodia pendens mengandung senyawa golongan flavonoid dan tanin sedangkan fraksi airnya mengandung senyawa golongan saponin,flavonoid dan glikosida.

\section{Uji Aktivitas Sitotoksik Metode Bhrine Shrimp Lethality Test (BSLT)}

Fraksi yang diperoleh dilakukan uji aktivitas sitotoksik dengan metode BSLT berdasarkan nilai konsentrasi letal $\left(\mathrm{LC}_{50}\right)$ pada hewan uji Artemia salina Leach Lethal Concentration atau $\mathrm{LC}_{50}$ merupakan konsentrasi senyawa yang mematikan $50 \%$ dari populasi hewan uji dengan hasil seperti pada tabel 3 dan Grafik berikut :

Tabel 3. Hasil LC ${ }_{50}$ Fraksi Hasil Pemisahan Ekstraksi Cair-cair

\begin{tabular}{|c|c|}
\hline Fraksi & LC50 $(\mathbf{p p m})$ \\
\hline Fraksi n-heksana & 81,88 \\
Fraksi Etil Asetat & 25,831 \\
Fraksi Air & 78,68 \\
\hline
\end{tabular}

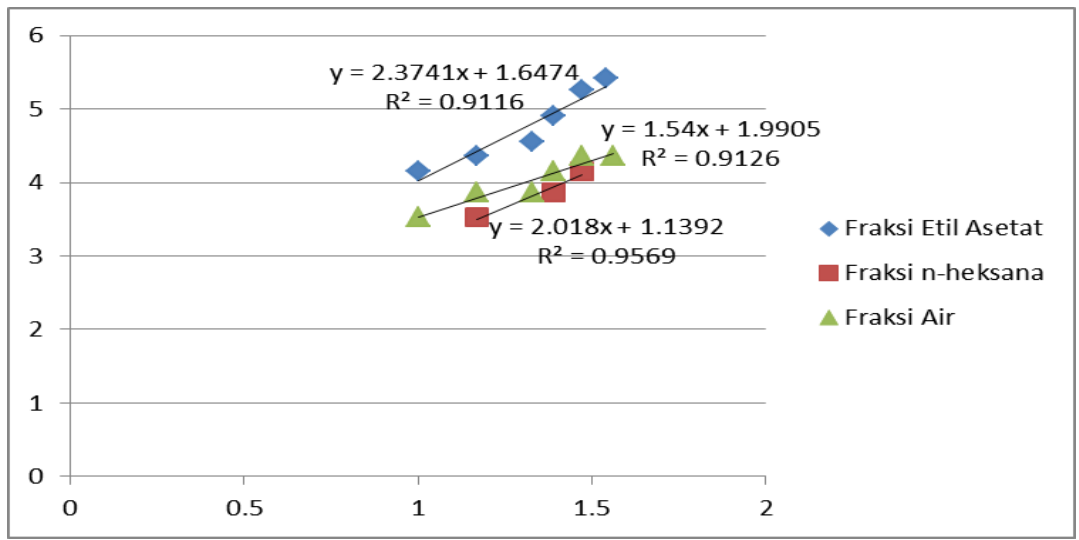

Grafik 1. Grafik kurva hubungan antara log konsentrasi dan nilai probit 
Dari data di atas diketahui bahwa fraksi etil asetat memiliki potensi aktivitas sitotoksik tertinggi terhadap larva A.sallina dari kedua fraksi dengan nilai IC50 25,831 ppm. Potensi aktivitas sitotoksik dari fraksi etil asetat diduga berasal dari senyawa golongan flavonoid dan tanin sesuai dengan hasil penapisan fitokimia sebelumnya. Dengan demikian fraksi etil asetat ini selanjutnya dipilih untuk proses isolasi senyawa aktif yang memiliki potensi senyawa aktif sitotoksik.

\section{Karakterisasi Isolat Fraksi dengan LC-MS}

Fraksi Etil Asetat yang memiliki nilai $\mathrm{LC}_{50}$ paling tinggi selanjutnya dilakukan karakterisasi menggunakan spektrofotometer LC-MS dengan hasil seperti pada grafik berikut:

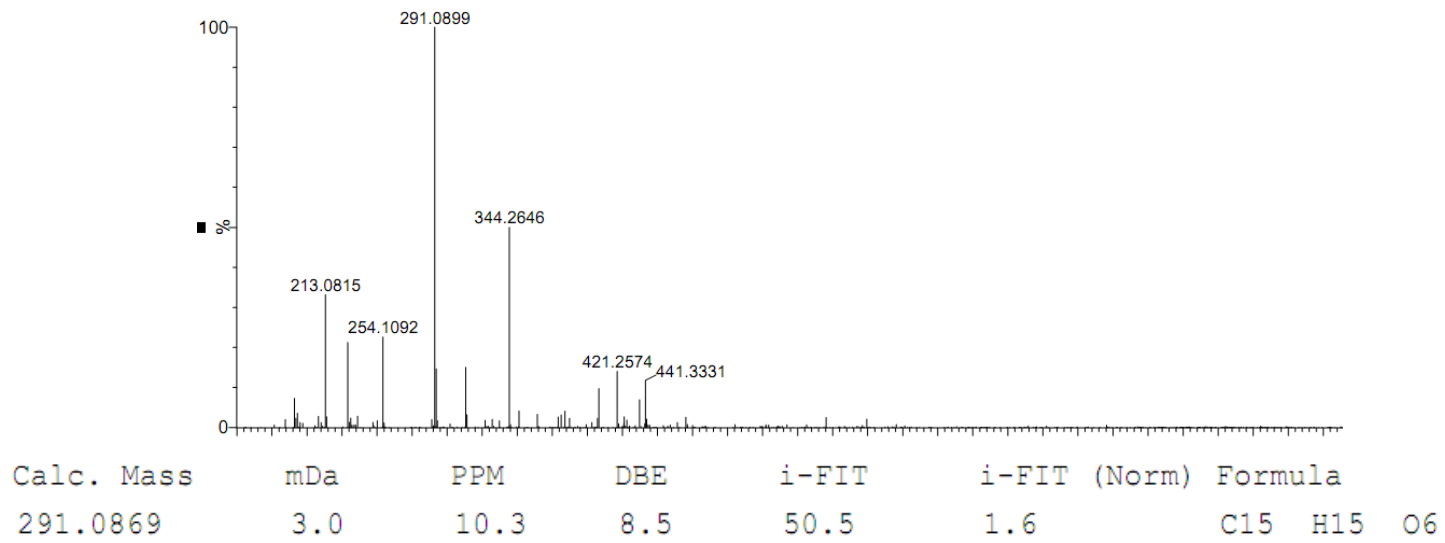

Grafik II. Grafik Fingerprint LC-MS fraksi Etil Asetat Peak 5,6 menit

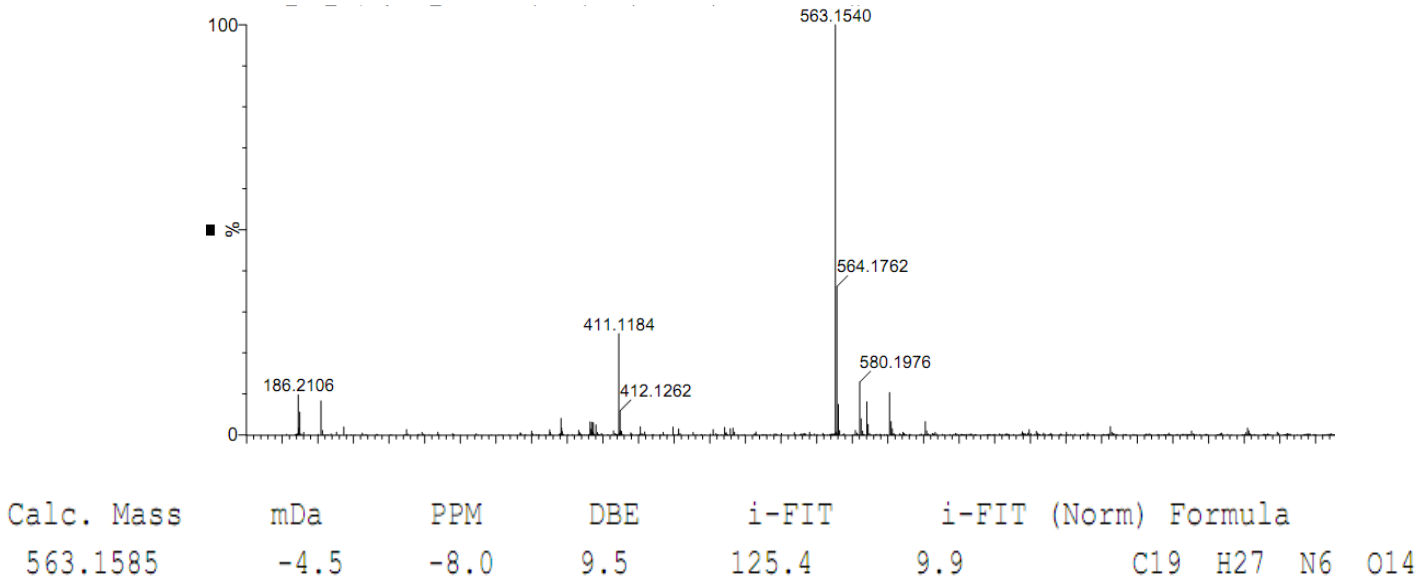

Grafik III. Grafik Fingerprint LC-MS fraksi Etil Asetat Peak 6,7 menit 


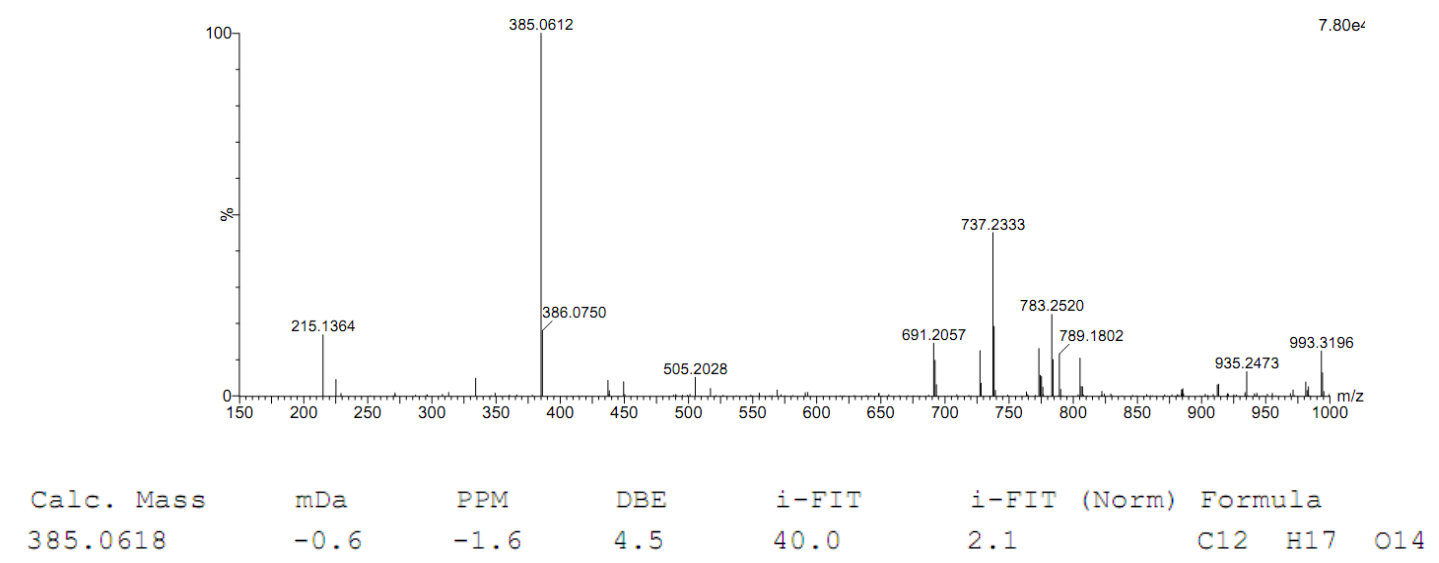

Grafik III. Grafik Fingerprint LC-MS fraksi Etil Asetat Peak 6,7 menit

Hasil analisis menggunakan LC-MS menunjukkan adanya tiga puncak, pada Peak 5,6 menghasilkan spektogram dengan berat molekul $291 \mathrm{~g} / \mathrm{mol}$, pada Peak 6,7 menghasilkan spektogram dengan berat molekul $563 \mathrm{~g} / \mathrm{mol}$ dan pada Peak 11-12 menghasilkan spektogram dengan berat molekul $385 \mathrm{~g} / \mathrm{mol}$.

\section{KESIMPULAN}

Fraksi etil asetat dari Myrmecodia beccarii Hook.f memiliki potensi paling tinggi dalam uji aktivitas sitotoksik dengan metode Bhrine Shrimp Lethality Test dengan nilai $\mathrm{LC}_{50} 25,831 \mathrm{ppm}$ daripada fraksi n-heksana dan fraksi air. Karakterisasi isolat dari fraksi etil asetat menggunakan LC-MS terdapat tiga puncak dengan masing-masing berat molekul 291, 563 dan $385 \mathrm{~g} / \mathrm{mol}$.

\section{ACKNOWLEDGE}

Terima kasih untuk seluruh tim peneliti Universitas Cenderawasih dan Institut Teknologi Bandung yang sudah melaksanakan kerja sama pada penelitian ini.

\section{DAFTAR PUSTAKA}

1. Natural. 2006. Senyawa Aktif Bersarang di Sarang Semut. Majalah Hal 18-19. Jakarta

2. Huxley, C.R. \& M.H.P. Jebb. (1993): The tuberous epiphytes of the Rubiaceae 5: A revision of Myrmecodia. Blumea 37:271-334

3. De Padua,L. (1999): Medicinal and Poisonous Plants, Plant Resources of South-East Asia, Prosea Foundation, Bogor.

4. Dirgantara, S., A.Nawawi., M. Insanu. (2013). Uji Aktivitas Antioksidan Tiga Spesies Tanaman Sarang Semut (Famili: Rubiaceae) Asal Kabupaten Merauke, Papua. Jurnal Biologi Papua., 5(1) :10-16

5. Hertiani,T., E. Sasmito, Sumardi and M. Ulfah. (2010): Preliminary Study on Immunomodulatory Effect of Sarang-Semut Tubers Myrmecodia tuberosa and Myrmecodia pendens. OnLine Journal of Biological Sciences 10 (3): 136-141.

6. Soeksmanto, A., M.A. Subroto, H. Wijaya and P. Simanjuntak. (2010): Anticancer activity for extracts of Sarang-Semut plant (Myrmecodia pendens) to HeLa and MCMB2 cells. Pakistan J. Biol. Sci., 13: 148-151.

7. Prachayasittikul, S., P. Buraparuangsang, A. Worachartcheewan, C. Isarankura-NaAyudhya, S. Ruchirawat and V. Prachayasittikul. (2008): Antimicrobial and antioxidative activities of bioactive constituents from hydnophytum formicarum jack. Molecules, 13: 904-921. 
8. Meyer BN, Ferigni NR, Putnam JE, Jaconsen LB, Nichols DF, Mc laughin JL. 1982. Brine Shimp A Convenient General Bioassay for Active Plant Constituents. Planta Medica 45, 31-34.

9. Franswort NR. (1966): Biological and Phytochemical Screenings of Plant. J. Pharm. Sci., 55(3):225-265. 